UDC 667.678.074

\title{
THE IMPACT OF COPOLYMERS SKN-40 AND EPTP-60 ON THE PROPERTIES OF BITUMEN COMPOSITIONS
}

\author{
D.S.MammadHasan-zade \\ Azerbaijan State Oil and Industry University \\ dilara.memmed1955@gmail.com
}

Received 23.10.2019

Accepted 05.03.2020

\begin{abstract}
Rubber mixtures were prepared on the base of butadiene-nitrile rubber SKN-40 (butadiene-nitrile rubber), copolymer EPTP-60 (ethylene-propylene triple copolymer), polyvinylchloride and MGF-9 (oligoether acrylate) in the research being conducted. As a result, heat resistance and adhesion were increased. The obtained rubber mixtures were added to the bituminous compositions as a result of which such parameters as penetration and extensibility improved.
\end{abstract}

Keywords: rubber, bitumen composition, lumps, black oil, rubber mixture.

doi

Currently, there exist serious problems with paving. Annually the transport load increases and the use of materials with low functional qualities leads to the fact that every three to four years requires major road repairs.

In the literature there is information about a positive impact on the elasticity and adhesive interaction of bitumen with rubbers or rubber based butadiene nitrile rubber $[1,2]$. In this paper, rubber mixtures were investigated on the base of nitrile rubber butadiene SKN-40, an ethylene-propylene triple copolymer EPTP-60, polyvinylchloride and oligo ether-acrylate MGF-9 were additionally introduced.

On the account the addition of EPTP-60, polyvinylchloride and MGF-9, it was possible to increase heat resistance by 3 times, as well as, relative elongation to 0.73 while maintaining high indexes of physical-mechanical properties of vulcanizers.

The procedure for preparing rubber mixtures was as follows: the mixtures were prepared on laboratory rolls at $30-40^{\circ} \mathrm{C}$. The total mixing duration is $20-25 \mathrm{~min}$. The vulcanization of rubber mixtures was carried out at $150^{\circ} \mathrm{C}$ for $30 \mathrm{~min}$. The formulation of rubber mixtures and physical-mechanical properties are given in Tables 1 and 2 respectively.

It can be seen from the data tables, in comparison with the known rubber mixture, the coefficient of heat resistance increased from
$0.3-0.4$ to $1.03-1.05$ relative to the extension from $0.55-0.65$ to $0.71-0.73$ in the obtained mixture.

We investigated the impact of the amounts of EPTP-60 and polyvinylchloride on the properties of rubber mixtures. It turned out that limits from 10 to 20 mass parts are optimal, since below 10 and above 20 mass parts the physical-mechanical properties of vulcanizers deteriorate.

If MGF-9 takes less than 3 mass parts in the rubber mixture based on the $\mathrm{SKN}-40$, EPTP-60 and polyvinylchloride, the compatibility and processing of the rubber mixture deteriorates. More than 3 mass parts also should not be used, since MGF-9 has a low molecular weight, which also deteriorates the physicalmechanical properties of vulcanizers.

Table 1. Formulation of rubber mixtures

\begin{tabular}{|c|c|c|c|}
\hline \multirow{2}{*}{$\begin{array}{c}\text { Nomination of the } \\
\text { components }\end{array}$} & \multicolumn{3}{|c|}{$\begin{array}{c}\text { Content of components in mass } \\
\text { parts }\end{array}$} \\
\cline { 2 - 4 } & $\begin{array}{c}\text { known rubber } \\
\text { mixture }\end{array}$ & \multicolumn{2}{|c|}{ proposed } \\
\hline SKN-40 & 100 & 80 & 60 \\
\hline EPTP-60 & - & 10 & 20 \\
\hline Polyvinylchloride & - & 10 & 20 \\
\hline Stearic acid & 1.5 & 1.5 & 1.5 \\
\hline Zink oxide & 5.0 & 5.0 & 5.8 \\
\hline Mercaptan & 0.8 & 0.8 & 0.8 \\
\hline benzithiazole & 1.5 & 1.5 & 1.5 \\
\hline Sulfur & 45 & 45 & 25 \\
\hline Carbon & - & 3 & 3 \\
\hline MGF-9 & & & \\
\hline
\end{tabular}


Table 2. Physical-mechanical indexes of vulcanizer

\begin{tabular}{|c|c|c|c|}
\hline \multirow{2}{*}{ Nomination of indexes } & \multicolumn{3}{|c|}{ Indexes } \\
\hline & 1 & 2 & 3 \\
\hline Extendibility strength, $\mathrm{MPa}$ & 30 & 28,5 & 29 \\
\hline Relative extension, \% & 550 & 530 & 545 \\
\hline Swelling in a mixture of benzene-gasoline (3:1) for 24 hours, $\%$ & $14-20$ & 16 & 18 \\
\hline Tear resistance, $\mathrm{kN} / \mathrm{m}$ & $72-85$ & 82 & 80 \\
\hline Hardness in TM, cosentional unlt & $72-76$ & 69 & 67 \\
\hline Elasticity in rebound, \% & $15-20$ & 22 & 24 \\
\hline Brittle point, ${ }^{0} \mathrm{C}$ & -23 & -25 & -27 \\
\hline $\begin{array}{l}\text { The coefficient of heat resistance }\left(\text { at } 100^{\circ} \mathrm{C}\right) \text { on: } \\
\text { Extendibility strength } \\
\text { Relative extension elongation }\end{array}$ & $\begin{array}{c}0,3-0,4 \\
0,55-0,65\end{array}$ & $\begin{array}{l}1,03 \\
0,71\end{array}$ & $\begin{array}{l}1,05 \\
0,73\end{array}$ \\
\hline $\begin{array}{l}\text { Ozone resistance }\left(25^{0} \mathrm{C}, 72 \mathrm{~h}, \mathrm{C}_{\mathrm{O}_{3}}=0.01 \text {, completely, deformation }\right. \\
20 \%)\end{array}$ & $\begin{array}{c}\text { broken down } \\
\text { within } 2 \text { hours }\end{array}$ & $\begin{array}{c}\text { not } \\
\text { broken down }\end{array}$ & $\begin{array}{l}\text { not bro- } \\
\text { ken down }\end{array}$ \\
\hline
\end{tabular}

Note: 1-component mixture in mass parts by 100 mass parts of rubber SKN-4-M mixture of 2,3-component in mass parts of polymer mixture SKN-40-EPTP-60-PVC.

Further to the obtained rubber mixture we added from 3-9 mass parts of PN-6m oil. The properties of the obtained rubber mixture are shown in Figure 1.

Based on the data received, in order to obtain the required vulcanized system, the ratio of the taken components should be regulated. For production, a rubber mixture of the following composition in mass parts by us was proposed:

$\mathrm{SKI}_{3}-85$, polyvinylchloride -10.0 , EPTP -60-50, sulfur - 2.5, $\mathrm{ZnO}-5$, captax -
$0.3,4010 \mathrm{HA}-1$, neozone $\mathrm{D}-1.0$, conifol -0.5 , stearic acid $-0.5, \mathrm{P} 4-1-2.0$, rubrux -4 , technical carbon P234 - 30 .

It turned out that the content of sulfur exerts a great impact on the vulcanization of the obtained mixture. At introducing to the mixture 2.5 mass parts, sulfur and 0.3 mass parts captax the cure time reduces from 20.8 to 16.6 seconds and the physical-mechanical characteristics of the compositions are improved.

Figure 2 shows the characteristics of vulcanizes depending on the sulfur content.

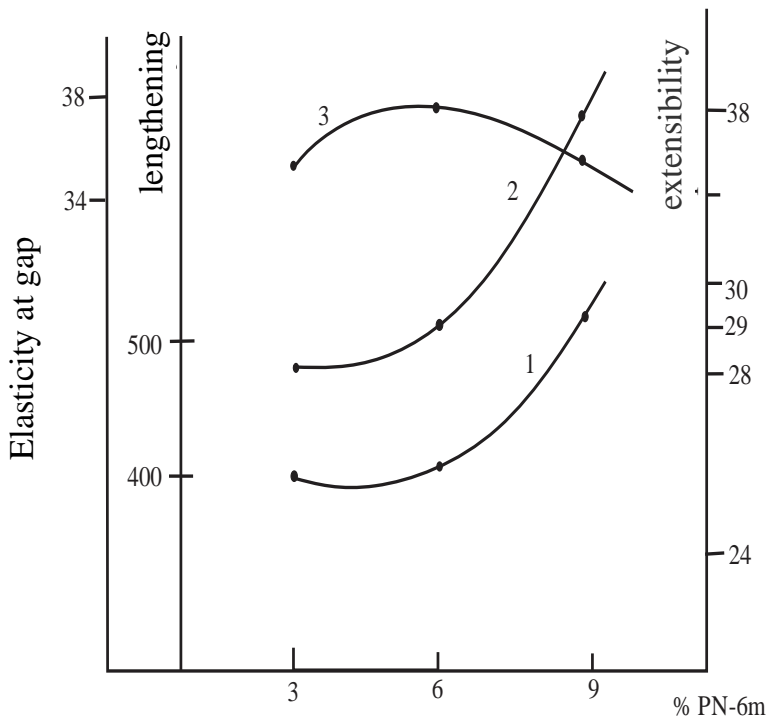

Fig.1. The main characteristics of the rubber mixture depending on the amount of oil PN-6m: $1-$ change the lengthening, 2 - tensile stress, 3 elasticity at gap.

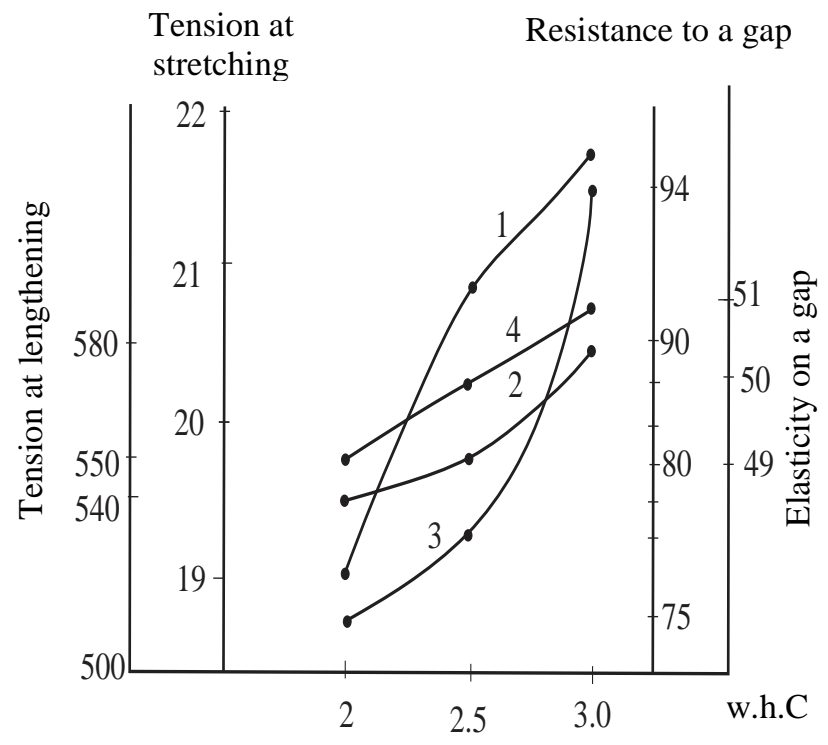

Fig.2. Characteristics of vulcanizers depending on the contents. 1-Tension at stretching; 2 Tension at lengthening; 3 -Resistance to a gap; 4 - Elasticity on a gap. 
The obtained rubber mixture was added to the bitumen compositions with purpose of obtaining road bitumen [3, 4].

Bituminous composition was prepared on the formulation [5].

In the content of the composition these were introduced: bitumen, lump, black oil and rubber mixture. As shown by experimental data, the content of black oil and rubber mixture has impact on the performance of the bituminous composition, that is seen from the graphs 3 and 4 .

As it is seen from the constructed graphs, the best bitumen composition is as follows: bitumen -73.5 , lumps -2.2 , black oil -22.1 and rubber mixture $-3.1 \%$.

Thus, as a result of the conducted research, the action mechanism of saturated pol- ymers on rubber from unsaturated rubbers containing EPTP, it was found that the main reason for their high heat resistance is the enrichment of the EPTP-60 from the surface layer during mechanical processing of the mixture. It was established that, while being introduced into the rubber mixture based on SKN-40, EPTP-60 and $\mathrm{PVC}$, the heat resistance of vulcanizers is increased, with MGF-9 and PVC resulting in the compatibility having been improved in the system SKN-40-EPTP-60-PVC.

The addition of the obtained rubber mixtures to bituminous compositions made it possible to improve such parameters as penetration and extensibility.

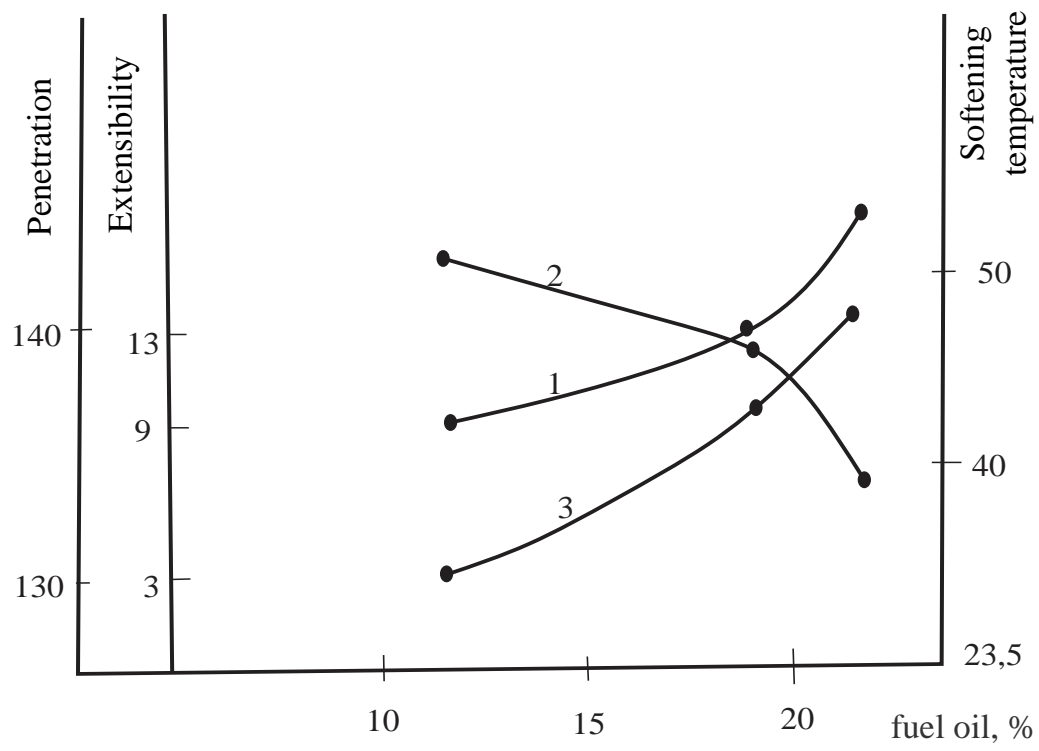

Fig.3. Dependence of bitumen composition qualities on black oil content: 1 - softening temperature, 2 - penetration; 3 extensibility.

Softening temperature

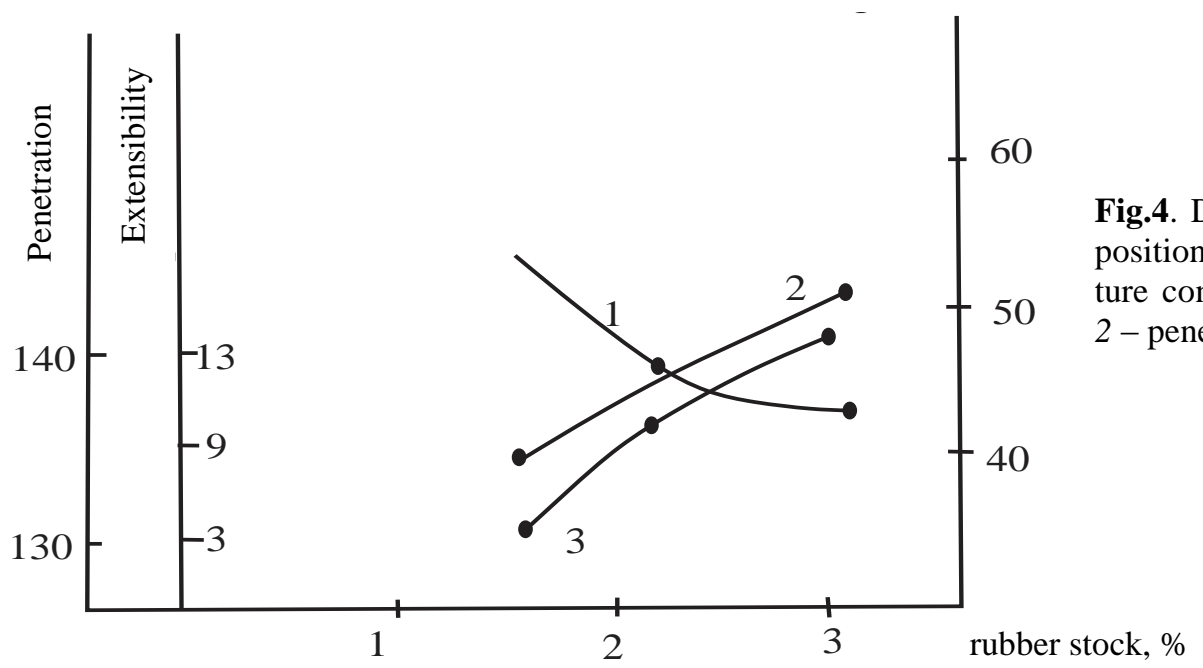




\section{References}

1. Kiselev V.P Use of products of joint processing of stone and brown coals, oil residues and polymer waste. News of high educational institutions. Building, 2008. P.17-22.

2. Sharipov V.I. and others. Obtaining binders for road construction from mixtures of brown coal, oil residues and polymer waste. Chemistry for Sustainable Development. 2005. P. 655-662.
3. Kotov S.V. Timofoeva G.V. Livanova S.V. Chemistry and Technology of Heat and Oils. 2003. P.52-53.

4. Mullahmedov N.R. Modification of road bitumen rubber. Bulletin of Kazan Technological University. 2010. P. 467-468.

5. Mukhanmaddinov I.I., Galimullin I.N. Oil refinery and oil-chemistry. 2017. N2. P. 33-37.

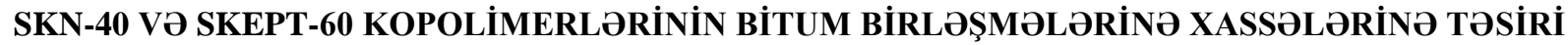 \\ D.S.MəmmədHəsən-zadə}

Aparılmış tədqiqatlarda SKN-40, kopolimer SKEPT-60, polivinilxlorid və MQF-9 əsaslı rezin qarışı̆̆ı hazırlanmışdır. Nəticədə istilik müqaviməti və yapışma xassələri artmışdır. Alınmış rezin qarışıqları bitum kompozisiyalarına əlavə olunmuş və nəticədə penetrasiya və genişlənmə xassələri yaxşılaşmışdır.

Açar sözlor: rezin, bitum kompopozisiyası, kauçuk, rezin qarışı̆̆ı.

\section{ВЛИЯНИЕ СОПОЛИМЕРОВ СКН-40 И СКЭПТ-60 НА СВОЙСТВА БИТУМНЫХ КОМПОЗИЦИЙ}

\section{Д.С.МамедГасан-заде}

В проведенных исследованиях были приготовлены резиновые смеси на основе бутадиен-нитрильного каучука СКН-40 (бутадиен-нитрильный каучук), сополимера СКЭПТ-60 (этилен-пропиленовый тройной сополимер), поливинилхлорида и МГФ-9 (олигоэфиракрилат). В результате увеличена теплостойкость и адгезия. Полученные резиновые смеси добавлялись к битумным композициям в результате чего улучшены такие показатели как пенетрация и растяжимость.

Ключевые слова: каучук, битумная композичия, глыбы, мазут, резиновый смесь. 